\title{
PENGGUNAAN BAHASA DALAM PELAYANAN PERIZINAN SANTRI DI KANTOR KEAMANAN PONDOK PESANTREN PUTRI UTARA DARUSSALAM BLOKAGUNG BANYUWANGI :KAJIAN SOSIOLINGUISTIK
}

\author{
Isti Nafiatus Sholichah
}

\section{IAI Darussalam Blokagung Banyuwangi}

Istynafiatussholichah@gmail.com

\begin{abstract}
Abstrak
Penelitian ini di laksanakan dengan tujuan mendeskripsikan tentang penggunaan bahasa yang dilakukan oleh pelayan dengan pelanggan saat pelayanan izin berlangsung beserta faktor-faktor yang mempengaruhinya. Penelitian ini menggunakan teori Dell Hymes, yaitu SPEAKING. Metode yang digunakan yaitu metode kualitatif dengan tujuan memaparkan penggunaan bahasa pelayan dan faktor-faktor yang mempengaruhi keragaman bahasa di kantor keamanan.Metode pengumpulan data dalam penelitian ini menggunakan teknik simak bebas libat cakap. Metode penyimakan dilakukan dengan teknik catat ketika percakapan sedang berlangsung. Data yang sudah diperoleh dideskripsikan lalu dipilah sesuai dengan data yang di temukan. Adapun bahasa-bahasa yang dipakai oleh pelayan dalam pelayanan izin santri setidaknya ada tiga bahasa (Jawa, Osing, dan Indonesia). Faktor-faktor penggunaan bahasa yang mempengaruhi bahasa yang digunakan pelayan di kantor keamanan dan ketertiban berupa faktor usia, saling menghormati, dan keakraban. Hasil dari penelitian ini yaitu terdapat tiga bahasa yang digunakan dalam pelayanan perizinan santri. Adapun bahasa yang digunakan adalah bahasa Jawa, bahasa Osing, dan bahasa campuran. Kata kunci: Sosiolinguistik, Penggunaan Bahasa, Pelayan, Kantor Kemanan, Izin Santri.
\end{abstract}

\section{Abstract}

This research was conducted with the aim of describing the use of language performed by the waiter and the customer during the permit service along with the factors that influence it. This research uses Dell Hymes theory, namely SPEAKING. The method used is a qualitative method with the aim of describing the use of servant language and the factors that affect the diversity of languages in the security office. The method of data collection in this study uses the technique of listening to the language of the service free. The method of listening is done by taking notes while the conversation is taking place. The data that has been obtained are described and then sorted according to the data found. There are at least three languages used by the maids in the student permit service (Javanese, Osing, and Indonesian). The factors of language use that influence the language used by servants in security and order offices are age, mutual respect, and familiarity. The result of this research is that there are three languages used in the licensing service for students. The languages used are Javanese, Osing, and mixed languages. 
Keywords: Sociolinguistics, Use of Language, Servants, Office of Security, Santri Permit.

\section{A. Pendahuluan}

Suatu anggota masyarakat dalam suatu bahasa terdiri dari berbagai status sosial dan latar belakang budaya yangberbeda. Hal ini terjadi karena bahasa yang digunakan oleh suatumasyarakat berbeda-beda sehingga membuat Indonesia kaya akan bahasa (Chaer, $2012: 55$ ).

Penggunaan bahasa memiliki tingkatan yang sesuai dengan konteks dalam percakapan tersebut. Penggunaan bahasa yang terjadi dapat dilihat melalui bahasa yang digunakan dari segi penutur berdasarkan dialek sosial dan sosiolek. Dalam sosiolek mengkaji perbedaan pemakaian variasi bahasa atau ragam bahasa yang berdasarkan status, golongan, dan kelas sosial. Disamping itu juga, pemakaian bahasa juga dipengaruhi oleh faktor-faktor situasional, yaitu siapa yang berbicara, dengan bahasa apa, kepada siapa, kapan, dimana, dan apa yang dibicarakan(Suwito dalam 1983:3).

Kegiatan komunikasi yang dilakukan santri pondok pesantren putri utara Darussalam di kantor keamanan dan ketertiban menunjukkan adanya keberagaman dalam penggunaan bahasa, seperti bahasa Jawa, Osing, dan Campuran.. Hal ini senada dengan penelitian Indah Kurnia Wati(2018) dalam penelitiannya yang berjudul “Pemakaian Bahasa Pedagang dalam Transaksi Penjualan Di Pasar

Kedinding Surya Surabaya: Kajian Sosiolinguistik" dengan hasil penelitian penggunaan bahasa pedagang di pasar Kedinding Surya Surabaya terdapat keragaman bahasa dalam melakukan komunikasi. Pedagang yang berasal dari etnis Madura maupun etnis Jawa merupakan masyarakat yang multilingual.

Data penelitian menunjukkan bahasa yang digunakan oleh pedagang saat transaksi penjualan terjadi terdapat bahasa Jawa, bahasa Madura, dan bahasa campuran. Asumsi ini diperkuat lagi dengan penelitian Ramendra (2013) bahwasannya variasi pemakaian bahasa pada masyarakat tutur kota Singaraja yang dikaitkan dengan wangsa, pekerjaan, dan umur. Selain itu, penelitian tersebut menguraikan faktor-faktor yang memengaruhinya. Dalam hasil penelitiannya terdapat tiga variasi bahasa pada masyarakat tutur kota Singaraja. 
Kedua penelitian tersebut relevan dalam hal adanya penggunaan bahasa yang sering terjadi di masyarakat. Hal inilah yang melatarbelakangi diadakannya penelitian, karena peneliti ingin mengetahui lebih jauh tentang penggunaan bahasa yang berada di dalam pondok pesantren putri utara Darussalamdalam hal pelayanan perizinan santri di kantor keamanan dengan menggunakan kajian teori sosiolinguistik.

\section{B. Landasan Teori}

\section{Pengertian Sosiolinguistik}

Sosiolinguistik merupakan gabungan dari kata sosiologi dan linguistik. Sosiolinguistik merupakan disiplin ilmu yang menggabungkan antara sosiologi dan linguistik yang saling terkait antar keduanya. Ilmu sosiologi merupakan kajian yang objektif mengenai manusia yang ada di masyarakat. Sedangkan linguistik merupakan ilmu yang mengkaji bahasa sebagai kajian objeknya.

Jadi sosiolinguistik adalah cabang ilmu yang mempelajari bahasa yang kaitannya dengan penggunaan bahasa yang ada di masyarakat. Bahasa dijadikan sebagai objek. (Chaer, $2012: 2$ ).

Masyarakat Tutur

Suwito dalam Kunjana (2015) mengatakan bahwasannya suatu masyarakat dapat dikatakan masyarakat tutur apabila sekelompok masyarakat tersebut memiliki verbal repertoire yang sama dan memiliki penilaian yang sama pula terhadap norma-norma pemakaian bahasa yang digunakan dalam masyarakat tersebut. Istilah verbal repertoire secara mudah dapat dikatakan kemampuan komunikatif yang dimiliki individu ataupun kelompok.

Peristiwa Tutur

Peristiwa tutur (Inggris:speech event) adalah terjadinya atau berlangsungnya interaksi linguistik dalam satu bentuk ujaran atau lebih yang melibatkan dua pihak, yaitu penutur dan lawan tutur, dengan satu pokok tuturan di dalam waktu, tempat, dan situasi tertentu. Jadi, interaksi yang berlangsung antara seorang pedagang dan pembeli dipasar pada waktu tertentu dengan menggunakan bahasa sebagai alat komunikasi adalah sebuah peristiwa tutur (Chaer dan Leoni, 2004:47). Jadi, bertemunya dua orang atau lebih dalam suatu tempat, waktu, dan dalam satu topik pembahasan maka situasi itulah yang dinamakan peristiwa tutur. Tindak Tutur 
Chaer (2004) mengatakan peristiwa tutur merupakan peristiwa sosial karena menyangkut pihak-pihak yang bertutur dalam satu situasi dan tempat tertentu. Peristiwa tutur ini pada dasarnya merupakan rangkaian dari sejumlah tindak tutur (Inggris:speech act) yang terorganisasikan untuk mencapai satu tujuan. Kalau peristiwa tutur merupakan gejala sosial seperti disebutkan diatas, maka tindak tutur merupakan gejala individual, bersifat psikologis, dan keberlangsungannya ditentukan oleh kemampuan bahasa si penutur dalam menghadapi situasi tertentu.

Kalau dalam peristiwa tutur lebih dilihat pada tujuan peristiwanya, akan tetapi dalam tindak tutur lebih dilihat pada makna atau arti tindakan dalam tuturannya.tindak tutur dan peristiwa tutur merupakan dua gejala yang terdapat pada satu proses, yakni proses komunikasi.

Penggunaan Bahasa

Pengertian Bahasa

Bloomfield dalam Sumarsono (2017) memberi pengertian bahasa adalah suatu lambang yang berupa bunyi bersifat sewenang-wenang (arbiter) yang digunakan oleh anggota masyarakat untuk saling bekerjasama, berinteraksi, mengidentifikasi diri

Komponen Bahasa

Menurut seorang sosiolinguistik terkenal Hymes (dalam Aslinda dan Leni, 2014:32) suatu peristiwa tutur harus delapan komponen yang diakronimkan menjadi SPEAKING. Kedelapan kedelapan tersebut adalah Setting and Scene, Participant, Ends, Act Sequences, Key, Instrumentalities, Norm Of Interaction and Interpretation, and Genres.

Setting berhubungan dengan waktu dan tempat pertuturan berlangsung, sementara scene mengacu pada situasi, tempat, dan waktu terjadinya pertuturan. Waktu, tempat, dan situasi yang berbeda dapat menyebabkan penggunaan variasi bahasa yang berbeda. Percakapan yang dilakukan dilapangan sepak bola ketika ada pertandingan dengan situasi yang ramai, tentu akan berbeda dengan percakapan yang dilakukan di perpustakaan pada waktu banyak orang yang sedang membaca dalam situasi yang sunyi.

Participants adalah peserta tutur, atau pihak-pihak yang terlibat dalam pertuturan, yakni adanya penutur dan mitra tutur. Status sosial partisipan menentukan ragam 
bahasa yang digunakan, misalnya seorang jaksa dalam persidangan akan berbeda ragam bahasa yang digunakan, ketika berbicara dengan anak-anaknya di rumah.

Ends mengacu pada maksud dan tujuan pertuturan. Dalam ruang seminar misalnya,penyaji erusaha menjelaskan maksud yang dibuatnya, sementara pendengar (peserta) sebagai mitra tutur berusaha mempertanyakan makalah yang disajikan penutur.

Act Sequences berkenaan dengan bentuk ujaran dan isi ujaran. Bentuk berkaitan dengan kata-kata yang digunakan, sementara isi berkaitan dengan topik pembicaraan.

Key berhubungan dengan nada suara (tone) penjiwaan (spirit), sikap atau cara (manner) saat sebuah tuturan diujarkan, misalnya dengan gembira, santai, dan serius.

Instrumentalities berkenaan dengan saluran (channel) dan bentuk bahasa (the form of speech) yang digunakan dalam pertuturan. Saluran misalnya oral, tulisan, isyarat, baik berhadap-hadapan maupun melalui telepon untuk yang saluran oral, tulisan bisa juga dengan telegraf.

Norms of Interaction and Interpretationadalah norma-norma atau aturan yang harus dipahami dalam berinteraksi. Norma interaksi dicerminkan oleh tingkat oral atau hubungan sosial dalam sebuah masyarakat bahasa.

Genre mengacu pada bentuk penyampaian, seperti puisi, pepatah, doa, dan sebagainya ( Chaer dan Agustina dalamAslinda, 2014:33).

Ragam Bahasa

Kemunculan ragam bahasa disebabkan oleh perbedaan bahasa yang digunakan dalam lingkungan masyarakat. Keberagaman bahasa timbul sebagai kebutuhan penutur memilih bahasa yang dipakai agar sesuai dengan konteks sosialnya. Dalam kajian sosiolinguistik ragam atau variasi bahasa merupakan bahasa pokok, sehingga menurut Kridalaksana (dalam Chaer dan Leonie 2010 : 61) mendefinikasikan sosiolinguistik merupakan cabang ilmu linguistik yang menjelaskan ciri-ciri bahasa dan ciri sosial kemasyarakatan.

Layanan santri

Header Daulymengatakan "santri merupakan sebutan bagi siswa yang belajar dalam pesantren”.Santri terbagi menjadi dua 
1. Santri mukim, yaitu santri yang berdatangan dari tempat-tempat yang jauh yang tidak memungkinkan dia untuk pulang ke rumahnya, maka dia mondok (tinggal) di pesantren.

2. Santri kalong, yaitu siswa-siswa yang berasal dari daerah sekitar yang memungkinkan mereka pulang ke tempat tinggal masing-masing.

Pondok Pesantren

Zamakhsyari Dhofier (2001) mengatakan bahwa pondok pesantren merupakan tempat tinggal yang terbuat dari bambu. Pondok pesantren berasal dari bahasa Arab fundug yang berarti hotel atau asarama. Pondok pesantren adalah lembaga pendidikan islam yang dilaksanakan dengan sistem asarama (pondok), dengan Kyai yang mengajar ilmu agama islam kepada santri, dan Masjid sebagai pusat lembaganya pondok pesantren, yang cukup banyak jumlahnya.

Kantor keamanan menjadi objek penelitian ini, dimana tempat terjadinya interaksi dua arah yang berbeda, baik dari bahasa yang di gunakan baik dari pelayan ataupun pelanggan. Pelayanan santri yang paling banyak diminati dan melakukan pelayanan adalah bagian jasa perizinan.

Jasa pelayanan perizinan meliputi: perizinan pulang bermalam, perizinan keluar kampus, perizinan sekolah formal dan perizinan madrasah diniyyah. Hasil dari jasa pelayanan perizinan yaitu berupa surat izin tertulis berstempel. Prosedur pelayanan perizinan dilakukan oleh petugas keamanan yang bertanggung langsung terhadap santri yang diberikan izin. Berikut ini data pengurus keamanan bagian perizinan:

Jenis Kelamin : Perempuan

Umur : $\quad 22$ Tahun

Asrama : Al Amni

Asal :Ogan Komering Ulu, Sumatera Selatan

Jenis Kelamin : Perempuan

Umur : 23 Tahun

Asrama : Al Amni

Asal : Papua

Jenis Kelamin : Perempuan

Umur : $\quad$ 23 Tahun 
Asrama $\quad$ : Al Amni

Asal : Banyuwangi

Berikut Ini Data Santri Saat Meminta Izin Kepada Pengurus Kantor Keamanan Pondok Pesantren Putri Utara Darussalam

Jenis Kelamin : Perempuan

Umur : 20 Tahun

Asrama : Nurul Jadidah

Asal : Sumatera Selatan

Jenis Kelamin : Perempuan

Umur : : 19 Tahun

Asrama : Nurud Darojah

Asal : Banyuwangi

Jenis Kelamin : Perempuan

Umur : 20 Tahun

Asrama : Al Fatimah Asal

: Papua

Jenis Kelamin : Perempuan

Umur : $\quad$ 18 Tahun

Asrama :Tuhfatun Nidhomiyyah

Asal : Jawa Barat

Jenis Kelamin : Perempuan

Umur : 19 Tahun

Asrama : Al Khodijah

Asal : Jawa Tengah

Jenis Kelamin : Perempuan

Umur $\quad$ : 17 Tahun

Asrama : Al Mukhtaroh

Asal : Jember

Jenis Kelamin : Perempuan

Umur : :23 Tahun 


$\begin{array}{ll}\text { Asrama } & : \text { Al Amni } \\ \text { Asal } & : \text { Banyuwangi } \\ \text { Jenis Kelamin } & : \text { Perempuan } \\ \text { Umur } & : \text { : } 18 \text { Tahun } \\ \text { Asrama } & : \text { As Saidiyyah } \\ \text { Asal } & : \text { Kalimantan } \\ \text { Jenis Kelamin } & : \text { Perempuan } \\ \text { Umur } & : 21 \text { Tahun } \\ \text { Asrama } & : \text { Darul Lughoh } \\ \text { Asal } & : \text { Bangkalan } \\ \text { Jenis Kelamin } & : \text { Perempuan } \\ \text { Umur } & : \text { 20 Tahun } \\ \text { Asrama } & : \text { Al Inaroh } \\ \text { Asal } & : \text { Surabaya }\end{array}$

\section{Metode Penelitian}

Jenis Penelitian

Penelitian ini menggunakan penelitian kualitatif yakni salah satu metode penelitian yang bertujuan untuk mendapatkan pemahaman tentang kenyataan melalui proses berfikir induktif. Melalui penelitian kualitatif, peneliti dapat mengenali subjek, merasakan apa yang mereka alami dalam kehidupan sehari-hari. Dalam penelitian ini, tentunya peneliti terlibat dalam situasi dan setting fenomena yang diteliti. Peneliti diharapkan selalu memusatkan perhatian pada kenyataan atau kejadian dalam konteks yang diteliti (Basrowi, 2008).

Subjek Penelitian

Spradley dalam Basrowi, (2008:188) mengatakan bahwa subjek penelitian merupakan sumber informasi, berbeda dengan pendapat yang dikemukakan Moleong dalam Basrowi, (2008:188) yang menyatakan bahwa subjek penelitian merupakan orang yang ada dalam latar penelitian.

Dalam penelitian ini, peneliti memfokuskan pada penggunaan bahasa yang digunakan dalam pelayanan izin santri yang dikaji dalam ranah sosiolinguistik, dalam mendeskripsikan data ini peneliti memaparkan tentang latar belakang penutur dan lawan tutur. 
Penelitian yang dilakukan di kantor keamanan dengan stadi kasus penggunaan bahasa dalam pelayanan izin santri, peneliti mengambil sepuluh sempel bahasa yang digunakan dalam layanan izin santri dan dilaksanakan selama jam kerja berlangsung.

Berikut ini data pengurus keamanan bagian perizinan santri saat melaksanankan layanan perizinan.

Tempat dan Waktu Penelitian

Waktu pelaksanaan penelitian dilakukan di bulan mei 2020 sampai dengan bulan juli 2020. Adapun tempat penelitian bertempat di kantor keamanan dan ketertiban pondok pesantren putri utara Darussalam Blokagung Tegal Sari Banyuwangi Jawa Timur.

Sumber Data

Sumber data dalam penelitian ini terbagi dua, yaitu sumber data primer dan sumber data sekunder. Data primer adalah data yang diperoleh secara langsung (dari tangan pertama), sementara data sekunder adalah data yang diperoleh peneliti dari sumber yang ada (Muhajir dan Maya, 2017 : 201).

Metode Pengumpulan Data

Metode pengumpulan data yang digunakan dalam penelitian kajian sosiolinguistik penggunaan bahasa dalam pelayanan santri di kantor keamanan pondok pesantren putri utara darussalam blokagung banyuwangi ini menggunakan metode simak, teknik sadap, teknik Simak Bebas Libat Cakap (SBLC), teknik rekam, dan teknik catat.

Metode Analisis Data

Moh Nasir menyatakan bahwa analisis data merupakan mengelompokkan, membuat suatu urutan, memanipulasi serta menyingkat data sehingga mudah untuk dibaca. Dalam menganalisis penelitian ini menggunakan metode deskriptif kualitatif, yakni penelitian yang menyajikan kajian dan analisis data secara langsung yang berhubungan antara peneliti dan informan yang telah terkumpul dari sumber data yang dipilih serta dianalisis berdasarkan data yang telah ditemukan. Tahapan dalam penelitian ini adalah mentranskip data yang berupa bentuk catatan percakapan pengurus keamanan kepada santri. Analisis ini 
dilakukan dengan mendeskripsikan penggunaan bahasa yang digunakan pelayan keamanan kepada pelanggan dengan menggunakan teori dari Dell Hymes (dalam Chaer dan Leoni, 2010:48) yaitu delapan komponen yang diakronimkan menjadi SPEAKING.

\section{Hasil dan Pembahasan}

1. Penggunaan Bahasa Dalam Layanan Izin Santri Di Kantor Keamanan Dan Ketertiban Pondok Pesantren Putri Utara Darussalam Blokagung Banyuwangi

Penggunaan bahasa dalam layanan izin santri di kantor keamanan, tentunya kita perlu mengetahui tuturan yang digunakan dalam komunikasi sehari-hari. Pelayanan izin santri dan pelanggan yang berada dalam satu tempat tentunya menggunakan lebih dari satu bahasa. Hal ini disebabkan karena pelayan perizinan dan pelanggan memiliki latar belakang dan etnis yang berbeda, seperti etnis Jawa, dan etnis Osing. Berdasarkan data yang dikumpulkan dari observasi dilapangan telah ditemukan pemakaian bahasa yang digunakan oleh pelayan dalam bahasa Jawa, Bahasa Osing dan bahasa campuran (Jawa, Osing, Indonesia).

\subsection{Penggunaan Bahasa Jawa Oleh Pelayan Perizinan di Kantor Keamanan}

Dari hasil penelitian ditemukan penggunaan bahasa jawa yang digunakan oleh pelayan perizinan yang berasal dari etnis jawa dan pelanggan dari etnis osing ketika melakukan pelayanan perizinan.

Dari hasil penelitian, hal tersebut dapat dilihat pada data di bawah ini.

\section{Data 1}

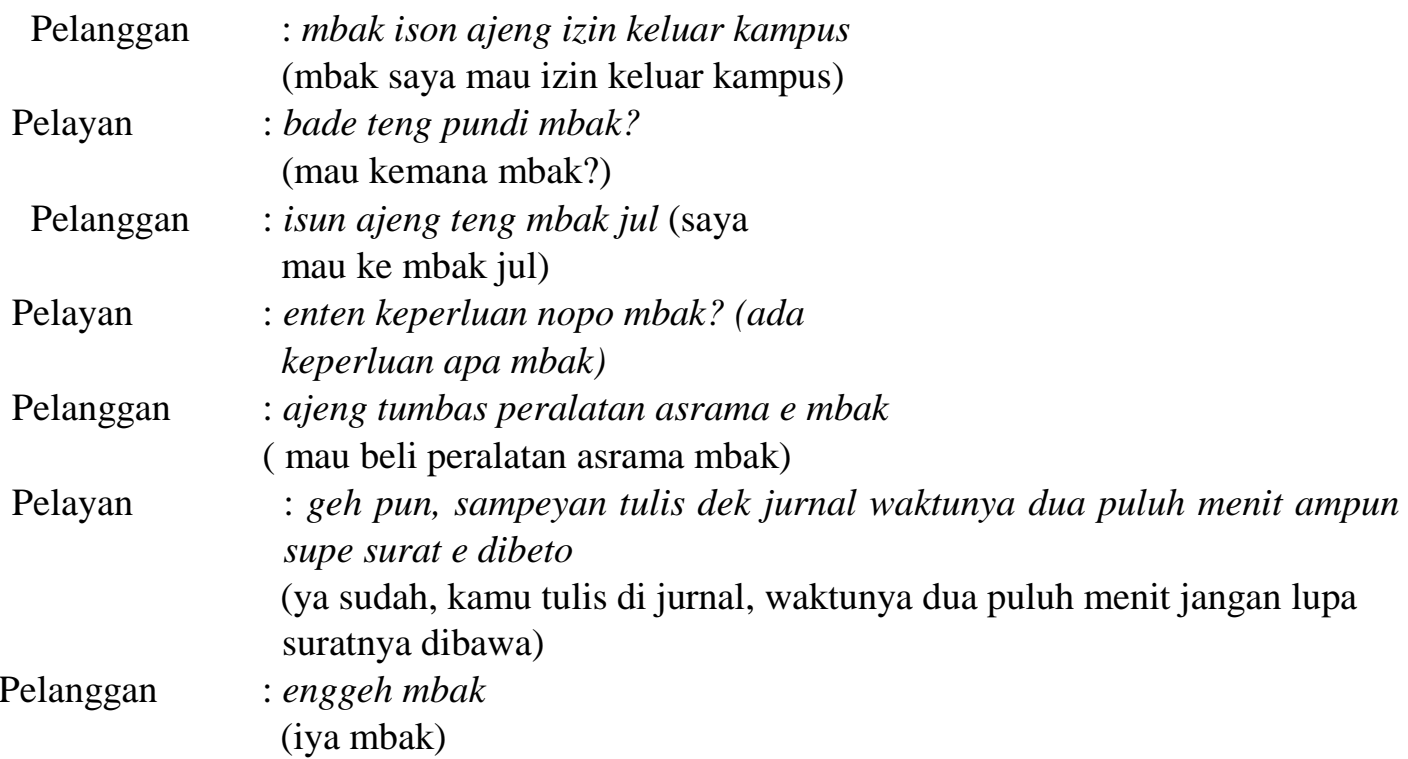


Bahasa yang digunakan dalam percakapan diatas menunjukkan dua bahasa yang berbeda, yaitu bahasa jawa krama dan bahasa osing. Bahasa jawa krama terlihat pada tuturan pelayan yakni kosakata nopo, enten, ampun, dan dibeto. Jika diartikan dalam bahasa jawa ngoko menjadi nopo (opo), enten (enek), ampun (ojo), supe (lali)dan dibeto (digowo).

Percakapan tersebut sering kali terjadi di kantor keamanan karena seseorang terbiasa menggunakan kata-kata yang dianggapnya nyaman Untuk berkomunikasi sehari-hari.

Nada yang digunakan pelayan dalam melayani pelanggannya tidak terlalu tinggi, dan tidak terlalu rendah, namun sopan dalam menuturkannya. Hal tersebut terlihat dari bahasa pelayan menggunakan bahasa jawa krama, walaupun pelanggan sedikit-sedikit menggunakan bahasa osing dengan logat khasnya.

Hal ini dikarenakan pelanggan yang menempat diasrama setiap hari berbaur dengan etnis jawa. Kesopanan terlihat dari bahasa yang digunakan pelayan yang menggunakan bahasa jawa krama kepada pelayang yang usianya lebih muda darinya. Jalur bahasa yang digunakan dalam percakapan tersebut menggunakan bahasa lisan dan langsung. Tidak ada norma atau aturan yang menyimpang dalam penggunaan bahasa yang pelayan dan pelanggan begitupun sebaliknya.

Bentuk penyampaian percakapan diatas, berupakan kalimat yang berisi pertanyaan dari pelayan dan pernyataan dari pelanggan.

\subsection{Penggunaan Bahasa Osing Oleh Pelayan Perizinan di Kantor Keamanan}

\section{Data 5}

Pelanggan : mbak ajeng tumbas surat izin pulang bermalam (mbak mau beli surat izin pulang bermalam)

Pelayan : sopo hang loro' mbak?

(siapa yang sakit mbak)

Pelanggan : warga asramane e mbak

(warga asrama mbak)

Data tersebut diperoleh dari percakapan yang terjadi di kantor keamanan pondok pesantren putri utara Darussalam Blokagung Banyuwangi. Komunikasi terjadi tepatnya pukul 16.00 WIB tanggal 17 Juli 2020. Pihak yang terlibat dalam tuturan tersebut adalah pelayan dan pelanggan. Pelayan berjenis kelamin perempuan dan berusia 22 tahun yang berlatar belakang dari etnis osing. Maksud dan tujuan penuturan tersebut pelanggan ingin membeli surat pulang beralam untuk 
warga asramanya. Pelanggan merupakan salah satu pengurus asrama. Bentuk ujaran dalam percakapan tersebut, pelayan menggunakan bahasa osing yang khas dengan logatnya, seperti “sopo hang loro' mbak?” yang artinya (siapa yang sakit mbak?), sedangkan pelanggan menggunakan bahasa Jawa.

Jalur bahasa yang digunakan pelayan dalam komunikasi dengan pelanggan menggunakan jalur lisan dan langsung. Norma pada percakapan pelanggan menggunakan nada sedang, tidak terlalu tinggi dan tidak terlalu rendah.

1.3 Penggunaan Bahasa Campuran Oleh Pelayan Perizinan di Kantor Keamanan Penelitian kali ini, ditemukan penggunaan bahasa Jawa, Osing, dan bahasa Indonesia yang digunakan oleh pelayan saat melakukukan perizinan di kantor keamanan. Berikut ini dapat dilihat dari data yang telah di peroleh dilapangan.

\section{Data 6}
Pelanggan : mbak mau beli surat izin diniyyah (mbak mau beli surat izin diniyyah)
Pelayan : pinten mbak? (berapa mbak?)
Pelanggan : satu surat pinten mbak regyane? (satu surat berapa harganya mbak?)
Pelayan : : lima ratus perak mbak, terserah sampeyan mau dijual berapa diasrama.
(lima ratus perak mbak, terserah kamu mau dijual berapa diasrama)
Pelanggan : : ngeh mbak, tumbyas kaleh doso ewu mbak (oh iya mbak, beli dua puluh ribu mbak)
Pelayan : o ngeh mbak (oh iya mbak)

Data diatas merupakan percakapan antara pelanggan dan pelayan di kantor keamanan. Percakapan diatas terjadi pada tanggal 17 Juli 2020 , dan pihak yang terlibat dalam tuturan tersebut adalah pelanggan dan pelayan. Dari percakapan tersebut, dapat kita ketahui bahwa pelayan yang mulanya menggunakan bahasa jawa krama, kemudian beralih menggunakan bahasa indonesia. Dapat kita ketahui dari percakapan berikut

Pelanggan : :satu surat pinten mbak regyane?

(satu surat berapa harganya mbak?)

Pelayan:lima ratus perak mbak, terserah sampeyan mau dijual berapa diasrama. (lima ratus perak mbak, terserah kamu mau dijual berapa diasrama)

Dari percakapan tersebut pelayan yang semula menggunakan bahasa jawa beralih menggunakan bahasa indonesia, hal ini disebabkan karena lawan tutur menggunakan bahasa Osing. Pelayan yang berasal dari etnis jawa, dan pelanggan 
yang berasal dari etnis Osing menjadi faktor penyebab terjadinya bahasa campuran dalam berkomunikasi. Maksud dan tujuan dari percakapan data (6) yaitu pelanggan ingin membeli surat izin diniyyah yang dikoordinir oleh salah satu pengurus asrama.

2. Faktor-Faktor yang Mempengaruhi Penggunaan Bahasa yang Terjadi Di

Kantor Keamanan Pondok Pesantren Putri Utara DarussalamDarussalam

Blokagung Banyuwangi

Penggunaan bahasa setiap individu yang ada di masyarakat akan mengalami keanekaragaman bahasa. Salah satu keanekaragaman bahasa yang terjadi di kantor keamanan, dan tidak pernah lepas dari layanan izin santri. Penggunaan bahasa oleh pelayan atau pelanggan di kantor keamanan terdapat faktor yang menyebabkan timbulnya keaneragaman bahasa tersebut, dengan konteks yang sesuai dengan peristiwa tuturan dalam menggunakan bahasa tersebut.

Kantor keamanan merupakan tempat terjadinya pelayanan izin santri yang berasal dari dari etnis yang berbeda, seperti bahasa Jawa, bahasa Osing dan Bahasa Indonesia. Berikut ini faktor-faktor yang mempengaruhi penggunaan bahasa di kantor keamanan pondok pesantren putri utara Darussalam.

\title{
2.1 Faktor Usia
}

Usia menjadi salah satu faktor dalam penggunaan bahasa yang ada di masyarakat. Keaneragaman yang terjadi di kantor keamanan berpengaruh terhadap respon pelayan kepada pelanggan saat pelayanan izin berlangsung. Kantor keamanan banyak di datangi dari berbagai usia. Banyak perbedaan bahasa yang terlihat apabila ditinjau dari siapa yang menggunakan bahasa. Hal ini dapat dilihat dari data berikut:

\author{
Data 4 \\ Pelanggan : :mbak laporan baru datang \\ (mbak laporan baru datang) \\ Pelayan : ningali rapote \\ (lihat rapotnya) \\ Pelanggan : niki mbak \\ (ini mbak) \\ Pelayan : lo kok terlambat nduk? \\ (loh kok terlambat) \\ Pelanggan : enggeh mbak, kemaren belum sembuh \\ (iya mbak kemarin belum sembuh) \\ Dari kutipan data di atas, pelayan menggunakan sapaan nduk kepada \\ pelanggan. Hal ini terjadi karena pelanggan memiliki usia lebih muda dari \\ pelanggan. Sehinggan sapaan tersebut sudah menjadi hal yang umum digunakan
}


oleh pelayan. Selain itu, bahasa yang digunakan oleh pelayan menggunakan Jawa krama kepada yang lebih muda, hal tersebut dimaksudkan untuk menghargai dengan yang lebih muda. 2.2 Faktor Saling Menghormati

Salah satu faktor yang mempengaruhi penggunaan bahasa pelayan di kantor keamanan yaitu saling menghormati antara pelayan dan pelanggan. Biasanya bentuk penghormatan ditujukan kepada orang yang ebih tua dan orang yang belum saling mengenal satu sama lain. Bentuk penghormatan pada umumnya diikuti dengan penggunaan bahasa yang lebih halus. Berdasarkan data yang diperoleh berikut ini: Data 6

Pelanggan : mbak mau beli surat izin diniyyah

(mbak mau beli surat izin diniyyah) Pelayan

: pinten mbak?

(berapa mbak?)

Dari data diatas, pelanggan dan pelayan sama-sama menggunakan panggilan mbak sebagai bentuk rasa saling menghormati.

\subsection{Faktor Keakraban}

Penggunaan bahasa yang terjadi di kantor keamanan diengaruhi oleh faktor hubungan keakraban, sehinggan timbul keanekaragaman bahasa. Hal ini tercermin dari sikap pelayan sebagai pengurus yang selalu siap siaga melayani perizinan santri.

\section{Data 1}

Pelanggan : mbak ison ajeng izin keluar kampus

(mbak saya mau izin keluar

kampus) Pelayan : bade teng pundi mbak? (mau

kemana mbak?)

Pelanggan : isun ajeng teng mbak jul (saya

mau ke mbak jul)

Pelayan : enten keperluan nopo mbak?

(ada keperluan apa mbak)

Pelanggan : ajeng tumbas peralatan asrama e mbak

( mau beli peralatan asrama mbak)

Pelayan : geh pun, sampeyan tulis dek jurnal waktunya dua puluh menit ampun supe surat e dibeto

(ya sudah, kamu tulis di jurnal, waktunya dua puluh menit jangan lupa suratnya dibawa)

Pelanggan : enggeh mbk

(iya mbak) 
Dari data tersebut, terlihat bentuk keakraban yang diberikan pelayan keamanan kepada pelanggan. Bentuk perhatian yang diberikan dengan mengingatkan kepada pelanggan untuk membawa surat jalannya.

\section{E. Simpulan dan Saran}

Berdasarkan penelitian Berdasarkan penelitian yang telah dilaksanakan dapat penulis simpulkan sebagai berikut:

1. Penggunaan bahasa dalam layanan izin santri di kantor keamanan pondok pesantren putri utara Darussalam Blokagung Banyuwangi terdapat keragaman bahasa dalam berkomunikasi seperti bahasa Jawa, bahasa Osing, dan bahasa campuran( Jawa, Osing, dan Indonesia)

2. penggunaan bahasa di kantor keamanan dan ketertiban dipengaruhi oleh beberapa faktor, seperti faktor usia, saling menghormati, letak geografis, dan keakraban.

Berdasarkan simpulan diatas maka penulis memberikan saran, dengan adanya penggunaan bahasa yang ada di kantor keamanan tentunya memunculkan hal lain yang tidak kalah menarik yakni masalah interferensi bahasa atau alih kode dan campur kode yang terjadi di kantor keamanan pondok pesantren putri utara Darussalam.

Diharapkan untuk penelitian selanjutnya dapat memberikan atau menambahkan beberapa sub topik yang dapat di eksplorasikan lebih lanjut dan menemukan hal baru pada gejala bahasa yag ada di kantor keamanan pondok pesantren putri utara Darussalam. Semoga penelitian ini dapat memberikan referensi serta manfaat bagi pembaca dan peneliti.

\section{Daftar Pustaka}

Aslinda, M. Hum \& Syafyahya, Leni. 2014. Sosiolinguistik. Bandung: PT Refika Aditama.

Basrowi \& Suwandi.2008. Memahami Penelitian Kualitatif.Jakarta: Rineka Cipta Chaer, Abdul. 2012. Linguistik umum. Jakarta: Rineka Cipta

Chaer, Abdul dan Leoni Agustina. 2004. Sosiolinguistik Perkenalan Awal. Jakarta: Rineka Cipta

Muhajir \& Panorama, Maya. 2017. Pendekatan Praktis Metode Penelitian

Kualitatif dan Kuantitatif. Yogyakarta:Idea Press 
Rahardi, Kunjana. 2015. Kajian Sosiolinguistik. Bogor: Ghalia Indonesia

Waty, Indah Kurnia. 2018. Pemakaian Bahasa Pedagang Dalam transaksi Penjualan Di Pasar Kedinding Surya Surabaya: Kajian Sosiolinguistik. Skripsi tidak di terbitkan. Surabaya: Fakultas Ilmu Budaya Universitas Air Langga Surabaya

Rahardi, Kunjana. 2015. Kajian Sosiolinguistik. Bogor: Ghalia Indonesia 